\title{
Modeling e-commerce adoption factors among Gen-Z in a developing country: the case of Ghana
}

\author{
Frederick Pobee \\ University of Pecs
}

\section{THE AIM OF THE PAPER}

This study aims to investigate the factors that influence e-commerce adoption among Gen $\mathrm{Z}$ in a developing country.

\section{METHODOLOGY}

A cross-sectional data were gathered from 522 Gen $\mathrm{Z}$ population in the most populous and industrious regions in Ghana. Partial Least Square- Structural Equation Modelling (PLS-SEM) was employed to assess the hypothesized relationships.

\section{MOST IMPORTANT RESULTS}

The findings indicate that effort expectancy, facilitating conditions, information quality, and system quality significantly affect the behavioral intention to adopt e-commerce among gen $\mathrm{Z}$ in Ghana. However, performance expectancy, social influence, and service quality had an insignificant effect on behavioral intention. This study is one of the few that have integrated the UTAUT model with DeLone and McLean IS success model to investigate e-commerce adoption. In a developing country context, and to the best of the author's knowledge, this is the first research to investigate the e-commerce adoption of a particular generation (Gen Z) in Ghana.

\section{RECOMMENDATIONS}

The paper concludes that the ease of using online shopping applications, the readiness and availability of support service for online purchases, information quality, and the efficiency and reliability of e-commerce systems significantly influence gen $\mathrm{Z}$ adoption of e-commerce. As a result, e-vendors and website business designers should ensure that the design and layout of e-commerce websites must be easy for consumers to navigate, provide a 24-hour consumer support system, and ensure efficiency and reliability of the e-commerce system.

Keywords: e-commerce adoption, gen Z, information quality, effort expectancy, systems quality

DOI: 10.15170/MM.2021.55.01.07 


\section{INTRODUCTION}

E-commerce, according to Awiagah et al. (2015), refers to an exchange of value (buying and selling) over the internet via computer networks. Over the years, developed countries have realized the economic and social benefits of e-commerce because they have successfully implemented and utilized e-commerce platforms. According to UNCTAD (2020), the global e-commerce revenue hits 25.6 trillion dollars, with America dominating the e-commerce market, alongside China and the United Kingdom. These countries have had the most e-commerce sales since 2017. UNCTAD (2019) business-to-customer (B2C) e-commerce index shows that the least developing countries, such as Guinea, Congo, Burundi, Chad, and Niger, have the lowest e-commerce index in the world. Even though there has been an increase in the awareness and benefits of e-commerce in developing countries, budget and technological constraints have prevented most developing countries from implementing and achieve the benefits that accompany e-commerce Some studies have reported inadequate national policies for e-commerce development, inadequate investment in telecommunication infrastructure, high cost of internet data, and lack of legal and economic regulatory climate as factors that impede e-commerce adoption in developing countries (Agwu \& Emeti 2014, Eraslan et al. 2016, Heang \& Khan 2015). Khan et al. (2017) indicate that a lot is being done by implementing good digital policies to influence e-commerce adoption irrespective of the challenges facing developing countries. Prior studies have explored e-commerce in developing countries from different perspectives (Rahayu \& Day 2015, Awiagah et al. 2015, Boateng 2016, Chiliya et al. 2011, Gorla et al. 2017, Pobee \& Opoku 2018b); however, research that focuses on a particular generation in developing countries have been shunned and overlooked by scholars. E-commerce adopters differ in generation, and each generation bears distinct technological characteristics that influence their perception of technology adoption. Until now, no research, arguably, has explored the e-commerce adoption behavior of generation $Z$, popularly known as gen $\mathrm{Z}$ in Ghana. This current research, therefore, fills the gap in the e-commerce literature by modeling the factors that influence gen $\mathrm{Z}$ in developing countries, particularly, Ghana to adopt e-commerce

Generation Z, popularly referred to as Gen-Z, comprises the people born between 1995 and the mid-2000s. This epoch is characterized by ext- ensive exposure to the world wide web (Wood 2013). Most of gen- $Z$ comprises of children of generation X. Generation X was born between 1965 to 1979. Research has shown (Wood 2013) that gen $\mathrm{Z}$ is perceived as a technology-savvy generation and has a comfort level with the global world. Attributes such as a focus on innovation, desire for security, and insistence on convenience have been attached to Generation Z (Wood 2013). Gen $Z$ inherently feels comfortable with the virtual world. This is because the internet has been with them since they were born. Therefore, an investigation into e-commerce adoption among gen $\mathrm{Z}$ in developing countries where technology adoption is relatively low compared to developed countries cannot be overemphasized.

\section{LITERATURE AND HYPOTHESIS DEVELOPMENT}

This study integrates the unified theory of acceptance and use of technology (UTAUT) and the DeLone and McLean IS success model factors to propose a research model that would serve as a theoretical lens to investigate e-commerce adoption. In adopting a multi-theory approach, this research uncovers the factors influencing Ghana's gen Z e-commerce adoption. Venkatesh et al. (2003) developed the UTAUT model to better understand user acceptance and use of technology. The UTAUT is made up of four primary constructs, namely, performance expectancy (PE), effort expectancy (EE), social influence(SI), and facilitating conditions (FC). The model holds that PE, EE, SI, and $\mathrm{FC}$ directly influence behavioral intention (BI). Many studies, including Alrajawy et al. (2016), Tarhini et al. (2018), and Pobee and Opoku (2018), have used the UTAUT to investigate user acceptance of technologies.

DeLone and McLean's IS success model measures the success factors influencing the adoption of information systems (DeLone \& McLean, 2003). Researchers have used the model, including Li \& Wang (2018) and Moorthy et al. (2017), to measure e-commerce success. While UTAUT measures the technology and social factors influencing technology adoption, DeLone \& McLean (2003) success model focuses on factors challenging information systems adoption. As a result, the author combined the UTAUT and DeLone and McLean IS success model in this research because each of these models has its own unique set of variables. Consequently, combining these models provides a compelling 
framework for uncovering the factors influencing e-commerce adoption. According to Fichman (2004) and Lyttinen \& Rose (2003), it is important to merge models to obtain a holistic understanding of a phenomenon. For this research, the antecedents of ATAUT, namely, performance expectancy, effort expectancy, social influence, and facilitating conditions, are combined with the DeLone and McLean IS success model's antecedents, namely, information, systems quality, and service quality.

\section{HYPOTHESES DEVELOPMENT}

\section{Performance Expectancy (PE)}

Performance expectancy measures the perceived gain associated with using a technology (Venkatesh et al. 2003). Prior studies have shown that performance expectancy plays a significant role in predicting behavior intention to adopt a system (Alrajawy et al. 2016, Tarhini et al. 2018, Venkatesh et al. 2011). Studies have proven that when performance expectancy increases, system usage also increases (Faaeq et al. 2014, Wu et al. 2007, Zhou et al. 2010). Extant studies have also suggested a significant relationship between performance expectancy and user behavior (Datta 2011, Lin \& Anol 2008, Moghawemi et al. 2012; Raman \& Don 2013, Raman et al. 2014). However, findings of Faraliza et al. (2014), Lian (2015), Singeh et al. (2013), and Yueh et al. (2015) reported an insignificant effect of performance expectancy on behavioral intention. For this study, PE is conceptualized as the gain associated with adopting e-commerce. The author assumed a significant relationship; hence, this study hypothesized:

H1: Performance expectancy significantly influences the behavioral intention of gen $Z$ in Ghana to adopt e-commerce.

\section{Effort Expectancy (EE)}

Effort expectancy measures the perceived ease associated with using a technology (Venkatesh et al. 2003). Prior studies have reported a significant effect of effort expectancy on behavioral intention (Madigan et al. 2016, Khalilzadeh et al. 2017, Aditya \& Pemadi 2018, Escobar-Rodríguez \& Carvajal-Trujillo 2014, Fang 2014, Hoque \& Sowar 2017). In contrast, findings of Guo (2015), Taiwo \& Mahmood (2012), Toh (2013), Yang (2013), Zhou et al. (2010) indicate an insignificant impact of effort expectancy on behavioral intention. For this study,
EE is conceptualized as the ease of using e-commerce applications. As such, the author assumed a significant relationship between EE and behavioral intention; hence, this study hypothesized:

H2: Effort expectancy significantly influences the behavioral intention of gen $Z$ in Ghana to adopt e-commerce.

\section{Social Influence (SI)}

According to Venkatesh et al. (2003), social influence measures the extent to which significant others such as family, friends, and media influence a person's intention to adopt the technology. Gonzalez et al. (2012) indicated that social influence has a significant effect on behavioral intention. This is consistent with the findings of Venkatesh et al. (2011), Escobar-Rodríguez \& Carvajal- Trujillo (2014), Hendarman and Tjakraatmadja (2014), Ifinedo (2012), Isaac et al. (2017), Martins et al. (2014). Contrariwise, the findings of Addo (2014), Faaeq et al. (2014), Faraliza et al. (2014), Nassuora (2013), and Nysveen \& Pedersen (2014) reported that social influence has an insignificant impact on behavioral intention. In the context of e-commerce, if close associates' perceptions play a role in users' decision to adopt or not adopt e-commerce, it is regarded as a social influence (SI). For this study, the author assumed a significant relationship between SI and behavioral intention, hence hypothesized;

H3: Social influence significantly influences the behavioral intention of gen $Z$ in Ghana to adopt e-commerce.

\section{Facilitating Conditions (FC)}

As opined by Venkatesh et al. (2003), facilitating conditions measure the availability of organizational and technological support to help users use technology. Guo (2015) suggested facilitating conditions significantly influence system use. Extant studies have also reported a significant effect of facilitating conditions on behavioral intention (Lin \& Anol 2018, Moghawemi et al. 2012, Sanchez et al. 2014, Wu et al. 2007, Chang 2013). Conversely, findings from Fang (2014), Lian (2015), Martins et al. (2014), Singeh et al. (2013), Yueh et al. (2015) indicate that behavioral intention is insignificantly influenced by facilitating conditions. For this study, FC is conceptualized as the availability of support services to users of e-commerce applications. The author assumed a significant relationship between FC and behavioral intention, therefore, hypothesized that: 
H4: Facilitating conditions significantly influence the behavioral intention of gen $Z$ in Ghana to adopt e-commerce.

\section{Information Quality (IQ)}

According to Liu \& Forsythe (2011), information quality refers to the information about products offered to consumers clearly and precisely. Findings of prior studies have suggested that information quality significantly influences e-commerce adoption. (Vasileiadis 2014, Abdennebi \& Debabi 2017, Liébana-Cabanillas et al. 2017). Similarly, Liu \& Forsythe (2011) suggested that information quality builds trust, influencing consumers to adopt e-commerce. In the context of e-commerce, information quality is measured by the clarity and precision of information displayed on the e-commerce website. The author perceived a significant relationship between IQ and behavioral intention, therefore hypothesized:

H5: Information quality significantly influence the behavioral intention of gen $Z$ in Ghana to adopt e-commerce

\section{Systems Quality (SQ)}

E-commerce system quality, according to Tarhini et al. (2018), refers to the availability, efficiency, reliability, and security of e-commerce websites. According to Vasileiadis (2014), buying products online is influenced by the online shopping platform's quality. Li \& Wang (2018) and Madan \&

Yadav (2018) suggested that system quality affects consumers' e-commerce adoption decisions. Similarly, Choi (2017) indicates that systems quality significantly impacts e-commerce adoption. This is consistent with Vasileiadis (2014) and Abdennebi \& Debabi (2017). In this research, systems quality is conceptualized as the reliability, efficiency, and security of an e-commerce website. The author assumed a significant relationship between SQ and behavioral intention, hence hypothesized:

H6: Systems quality positively influence the behavioral intention of gen $Z$ in Ghana to adopt e-commerce

\section{Systems Quality (SERQ)}

As opined by DeLone \& McLean (2003), service quality measures the organizational and technical support delivered by the e-vendor to the customers. Moorthy et al. (2017) and Hsu \& Yeh (2018) indicate service quality is a significant predictor of behavioral intention to adopt e-commerce. This is consistent with the findings of Heinze et al. (2017). Therefore, this study hypothesized:

H7: Service quality significantly influence the behavioral intention of gen $Z$ in Ghana to adopt e-commerce

Figure 1. Research model

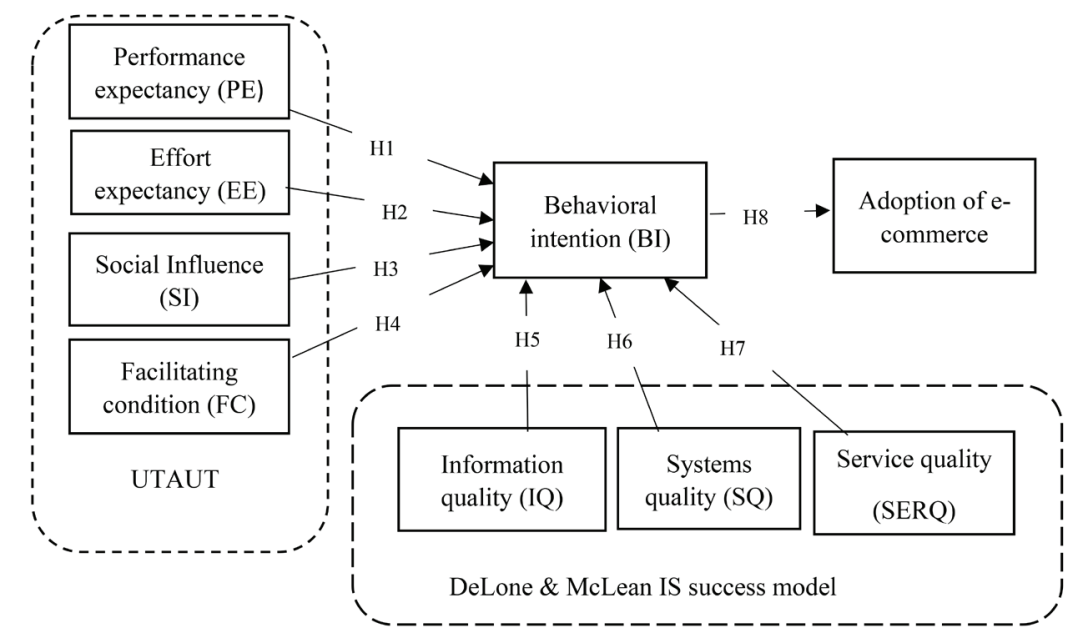

Author's construction 


\section{Behavioral Intention (BI)}

Behavioral intention is defined as "an individual subjective probability that he or she would like to engage in using a system (Fishbein \& Ajzen 1975). In this research, BI is contextualized as gen Z's subjective probability of using e-commerce. Many factors, as discussed earlier, can influence behavioral intention to adopt e-commerce. Furthermore, the impact of behavioral intention on the actual use of systems have also been reported in studies carried out in different disciplines (Hogue \& Sowar 2017, Madigan et al. 2016, Tarhini et al. (2018), Rahi et al. 2018, Raza et al. 2019, Savic \& Pesterac 2019). This study hypothesized:

H8: Behavioral intention positively influence the behavioral intention of gen $Z$ in Ghana to adopt e-commerce.

\section{METHODOLOGY}

\section{Participants and survey instrument}

The convenience data sampling technique was employed to collect data. An online survey questionnaire of 31 measuring items was used to gather data from Ghana's gen $\mathrm{Z}$ e-commerce users from September to November 2020. The questionnaire was divided into two sessions. The first session gathered data on the respondents' demographics, and the second session was on the questions related to the hypothesized variables. The survey was initially tested with two professors at the University of Pecs. Their feedback led the researcher to refine some of the questionnaire items to communicate well with respondents. An online survey was distributed to 630 gen $\mathrm{Z}$ e-commerce users in Ghana on a convenience sampling basis. Out of this number, 522 were fully completed and returned. This represents a response rate of eighty-three percent.

\section{Variables and measurement}

The research framework comprised variables from the UTAUT model (Venkatesh et al. 2003) and the DeLone and McLean IS model. The measurement items used were adapted from previous studies. Performance expectancy, effort expectancy, social influence was measured with four items each and facilitating conditions were measured with three items, and behavioral intention was measured with three items. These items were adapted from Venkatesh et al. (2003). Also, four items were used to measure information quality, systems quality, and service quality. These items were adapted from DeLone \& McLean (2003) and Tarhini et al. (2018). All items in the survey were measured on a fivepoint Likert scale ranging from 5 "strongly agree" to 1 "strongly disagree." The data was analyzed using PLS-Structural equation modeling.

Table 1. Survey questionnaire

\begin{tabular}{|c|c|c|c|}
\hline Construct & Item & Item text & Source \\
\hline \multirow[t]{4}{*}{$\begin{array}{l}\text { Performance expec- } \\
\text { tancy }\end{array}$} & PE1 & I would find e-commerce useful in my purchases & $\begin{array}{l}\text { Venkatesh et al. } \\
\text { (2003) }\end{array}$ \\
\hline & PE2 & $\begin{array}{l}\text { Using e-commerce enables me to accomplish my } \\
\text { purchases quickly }\end{array}$ & \\
\hline & PE3 & $\begin{array}{l}\text { Adopting e-commerce would add value to my } \\
\text { purchasing process }\end{array}$ & \\
\hline & PE4 & $\begin{array}{l}\text { Adopting e-commerce will increase my produc- } \\
\text { tivity }\end{array}$ & \\
\hline \multirow[t]{4}{*}{ Effort expectancy } & EE1 & $\begin{array}{l}\text { My interaction with the e-commerce platform } \\
\text { would be clear and understandable }\end{array}$ & \\
\hline & EE2 & $\begin{array}{l}\text { It will be easy for me to become skillful at using } \\
\text { e-commerce }\end{array}$ & \\
\hline & EE3 & I would find e-commerce easy to adopt & \\
\hline & EE4 & $\begin{array}{l}\text { Learning to operate an e-commerce platform } \\
\text { would be easy for me }\end{array}$ & \\
\hline
\end{tabular}




\begin{tabular}{|c|c|c|c|}
\hline \multirow[t]{4}{*}{ Social influence } & SI1 & $\begin{array}{l}\text { People who influence my behavior think I should } \\
\text { adopt e-commerce }\end{array}$ & \\
\hline & SI2 & $\begin{array}{l}\text { People who are important to me think I should } \\
\text { adopt e-commerce }\end{array}$ & \\
\hline & SI3 & $\begin{array}{l}\text { Friends suggestions and recommendations would } \\
\text { influence my adoption }\end{array}$ & \\
\hline & SI4 & $\begin{array}{l}\text { I will adopt e-commerce because other entrepre- } \\
\text { neurs have adopted }\end{array}$ & \\
\hline \multirow[t]{4}{*}{$\begin{array}{l}\text { Facilitating condi- } \\
\text { tions }\end{array}$} & $\mathrm{FC} 1$ & $\begin{array}{l}\text { I can get help from others when I have difficulty } \\
\text { using e-commerce }\end{array}$ & \\
\hline & FC2 & $\begin{array}{l}\text { I have the necessary knowledge to adopt e-com- } \\
\text { merce }\end{array}$ & \\
\hline & FC3 & $\begin{array}{l}\text { I have the resources necessary to adopt e-com- } \\
\text { merce }\end{array}$ & \\
\hline & FC4 & $\begin{array}{l}\text { A specific person (group) is available for assistance } \\
\text { with difficulties in using e-commerce platforms }\end{array}$ & \\
\hline \multirow[t]{4}{*}{ Information quality } & IQ1 & $\begin{array}{l}\text { The information generated by the e-commerce } \\
\text { website is correct }\end{array}$ & $\begin{array}{l}\text { DeLone and Mc- } \\
\text { Lean (2003) }\end{array}$ \\
\hline & IQ2 & $\begin{array}{l}\text { The information generated by the e-commerce } \\
\text { website is useful for its purpose }\end{array}$ & \\
\hline & IQ3 & $\begin{array}{l}\text { The e-commerce website generates information } \\
\text { on time }\end{array}$ & \\
\hline & IQ4 & $\begin{array}{l}\text { I trust the information output of the e-commerce } \\
\text { website }\end{array}$ & \\
\hline \multirow[t]{4}{*}{ Systems quality } & SQ1 & Interaction with the e-commerce website is reliable & \\
\hline & SQ2 & $\begin{array}{l}\text { I find it secure to put my personal information on } \\
\text { the e-commerce website }\end{array}$ & \\
\hline & SQ3 & The e-commerce system is efficient & \\
\hline & SQ4 & $\begin{array}{l}\text { The e-commerce website has a quick response } \\
\text { time }\end{array}$ & \\
\hline \multirow[t]{4}{*}{ Service quality } & SERQ1 & $\begin{array}{l}\text { There is adequate technical support from the } \\
\text { system's provider }\end{array}$ & \\
\hline & SERQ2 & $\begin{array}{l}\text { The overall infrastructure in place is adequate to } \\
\text { support me }\end{array}$ & \\
\hline & SERQ3 & $\begin{array}{l}\text { The e-commerce website can be relied on to } \\
\text { provide information as to when needed }\end{array}$ & \\
\hline & SERQ4 & $\begin{array}{l}\text { The output of the e-commerce website is complete } \\
\text { for purchasing processes }\end{array}$ & \\
\hline \multirow[t]{3}{*}{ Behavioral intention } & BI1 & $\begin{array}{l}\text { I intend to adopt and use e-commerce going } \\
\text { forward }\end{array}$ & $\begin{array}{l}\text { Venkatesh et al. } \\
\text { (2003) }\end{array}$ \\
\hline & BI2 & I would recommend my friends adopt e-commerce & \\
\hline & $\mathrm{BI} 3$ & $\begin{array}{l}\text { I would say positive things about adopting and } \\
\text { using e-commerce }\end{array}$ & \\
\hline
\end{tabular}

Author's construction 


\section{Data analysis}

The two-stage approach of structural equation modeling was employed. First was the measurement model assessment, and second, the structural model assessment. The measurement items were tested with CFA using the maximum likelihood estimation method to assess the items' reliability. All standardized factor loadings emerged high and significant. Factor loadings exceeded Hair et al. (2006) threshold of 0.70. The constructs showed an acceptable range of inter- nal consistency with Cronbach's alpha from 0.799 to 0.884 . The composite reliabilities revealed an internal consistency of each construct's items with composite reliability above 0.70 (Hair et al. 2006). According to Bagozzi \& Yi (2012) and Hair et al. (2006), the average variance extracted (AVE) of all constructs must be greater than or equal to 0.50 . Table 2 shows that the AVE of all the constructs is above 0.50 , explaining a large portion of the variance. The reliability analysis is shown in Table 2.

Table 2. Loadings of each variable and reliability analysis

\begin{tabular}{|c|c|c|c|c|c|}
\hline Constructs & Items & Loading & Cronbach's alpha & CR & AVE \\
\hline \multirow[t]{4}{*}{ Performance expectancy } & PE1 & 0.82 & 0.802 & 0.823 & 0.689 \\
\hline & PE2 & 0.792 & & & \\
\hline & PE3 & 0.852 & & & \\
\hline & PE4 & 0.845 & & & \\
\hline \multirow[t]{4}{*}{ Effort expectancy } & EE1 & 0.787 & 0.821 & 0.878 & 0.653 \\
\hline & EE2 & 0.721 & & & \\
\hline & EE3 & 0.802 & & & \\
\hline & EE4 & 0.824 & & & \\
\hline \multirow[t]{4}{*}{ Social influence } & SI1 & 0.788 & 0.799 & 0.781 & 0.601 \\
\hline & SI2 & 0.881 & & & \\
\hline & $\mathrm{SI} 3$ & 0.771 & & & \\
\hline & SI4 & 0.843 & & & \\
\hline \multirow[t]{4}{*}{ Facilitating conditions } & $\mathrm{FC} 1$ & 0.795 & 0.856 & 0.884 & 0.723 \\
\hline & $\mathrm{FC} 2$ & 0.894 & & & \\
\hline & FC3 & 0.843 & & & \\
\hline & $\mathrm{FC4}$ & 0.798 & & & \\
\hline \multirow[t]{4}{*}{ Information quality } & IQ1 & 0.876 & 0.84 & 0.834 & 0.678 \\
\hline & IQ2 & 0.862 & & & \\
\hline & IQ3 & 0.832 & & & \\
\hline & IQ4 & 0.842 & & & \\
\hline \multirow[t]{4}{*}{ Systems quality } & SQ1 & 0.821 & 0.872 & 0.865 & 0.711 \\
\hline & SQ2 & 0.748 & & & \\
\hline & SQ3 & 0.798 & & & \\
\hline & SQ4 & 0.839 & & & \\
\hline \multirow[t]{4}{*}{ Service quality } & SVQ1 & 0.885 & 0.884 & 0.842 & 0.721 \\
\hline & SVQ2 & 0.885 & & & \\
\hline & SVQ3 & 0.833 & & & \\
\hline & SVQ4 & 0.862 & & & \\
\hline \multirow[t]{3}{*}{ Behavioral intention } & BI1 & 0.882 & 0.837 & 0.879 & 0.649 \\
\hline & BI2 & 0.846 & & & \\
\hline & $\mathrm{BI} 3$ & 0.881 & & & \\
\hline
\end{tabular}


More so, the AVE values for the constructs exceeded the squared correlation of the construct and other constructs in the model (Chin et al. 2003), indicating a good discriminant validity (Table 3 ).

Table 3. Discriminant analysis

\begin{tabular}{|l|l|l|l|l|l|l|l|l|}
\hline & PE & EE & SI & FC & IQ & SQ & SERQ & BI \\
\hline PE & $\mathbf{0 . 8 3}$ & & & & & & & \\
\hline EE & 0.519 & $\mathbf{0 . 8 0 8}$ & & & & & & \\
\hline SI & 0.37 & 0.467 & $\mathbf{0 . 7 7 5}$ & & & & & \\
\hline FC & 0.455 & 0.519 & 0.419 & $\mathbf{0 . 8 5}$ & & & & \\
\hline IQ & 0.421 & 0.439 & 0.565 & 0.451 & $\mathbf{0 . 8 2 3}$ & & & \\
\hline SQ & 0.573 & 0.606 & 0.372 & 0.431 & 0.454 & $\mathbf{0 . 8 4 3}$ & & \\
\hline SERQ & 0.422 & 0.585 & 0.482 & 0.482 & 0.521 & 0.422 & $\mathbf{0 . 8 5}$ & \\
\hline BI & 0.529 & 0.631 & 0.468 & 0.517 & 0.31 & 0.543 & 0.439 & $\mathbf{0 . 8 0 6}$ \\
\hline
\end{tabular}

Diagonal elements (italics) in the matrix represent the square root of AVE Source: Author's construction

\section{Structural model estimation}

The structural model was estimated to test $\mathrm{H} 1$ to H8. The model estimation indicates the path coefficients, as shown in Figure 2. The bootstrapping method was used to estimate the statistical significance of the parameter estimates. Performance expectancy showed an insignificant influence on behavioral intention $(\beta=0.053$, t-value $=1.28)$ thereby, H1 was rejected. Effort expectancy showed a significant relationship with behavioral intention ( $\beta=0.207$, t-value $=6.23$ ), hence, $\mathrm{H} 2$ is supported. Social influence showed an insignificant association with behavioral intention $(\beta=0.032$, $\mathrm{t}$-value $=$ 1.02); therefore, H3 was not supported. Facilitating conditions showed a significant association with behavioral intention $(\beta=0.172$, t-value $=4.11)$; hence, H4 was supported. Information quality showed a significant influence on behavioral intention $(\beta=0.289$, $\mathrm{t}$-value $=6.85)$. Hence, $\mathrm{H} 5$ was supported. System quality had a positive and significant influence on behavioral intention $(\beta=0.151$, t-value $=3.05$ ). Hence, H6 was supported. Service quality showed an insignificant influence on behavioral intention $(\beta=0.046$, $\mathrm{t}$-value $=1.21)$. therefore, $\mathrm{H} 7$ was not supported. Finally, behavioral intention showed a positive and significant influence on e-commerce adoption $(\beta=0.179$, t-value $=4.19)$. Hence, H8 was supported. Figure 2 shows the path analysis and the beta coefficients and t-values of the variables. 
Figure 2. Empirical model

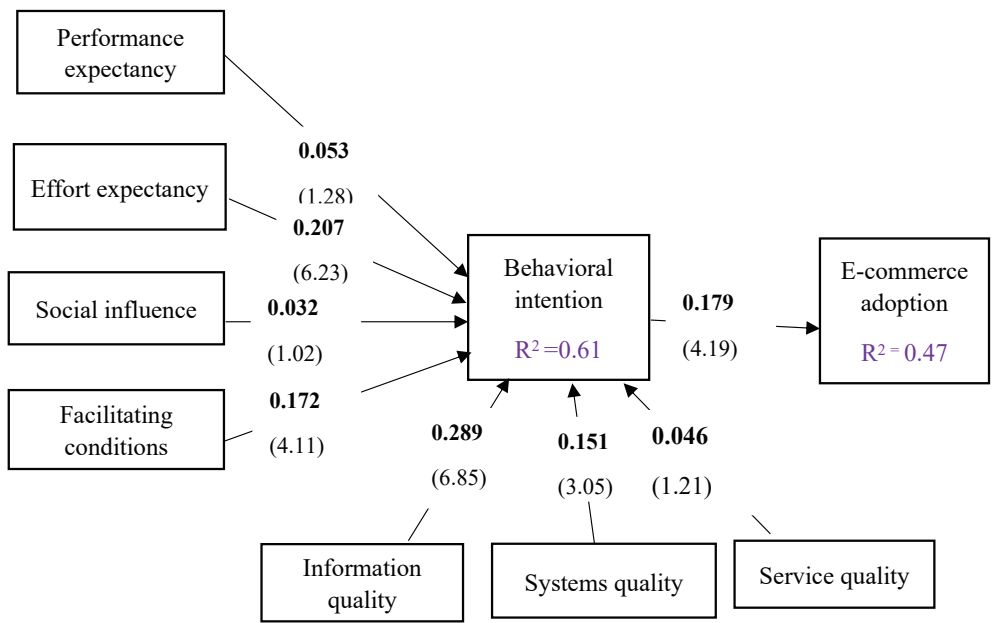

Note: figures in bold are beta coefficients, and figures in () are t-values Source: Author's construction

The summary of the results is presented in Table 4 .

Table 4. Summary of Results

\begin{tabular}{|l|l|l|l|l|}
\hline Hypothesis & Relationship & $\boldsymbol{\beta}$ estimate & t-values & Supported? \\
\hline $\mathrm{H} 1$ & $\mathrm{PE} \rightarrow \mathrm{BI}$ & 0.053 & 1.28 & No \\
\hline $\mathrm{H} 2$ & EE $\quad$ BI & 0.207 & 6.23 & Yes \\
\hline $\mathrm{H} 3$ & $\mathrm{SI} \rightarrow \mathrm{BI}$ & 0.032 & 1.02 & No \\
\hline $\mathrm{H} 4$ & FC $\rightarrow$ BI & 0.172 & 4.11 & Yes \\
\hline H5 & IQ $\rightarrow$ BI & 0.289 & 6.85 & Yes \\
\hline H6 & SQ $\rightarrow$ BI & 0.151 & 3.05 & Yes \\
\hline H7 & SERQ $\rightarrow$ BI & 0.046 & 1.21 & No \\
\hline H8 & BI $\rightarrow$ Adopt & 0.179 & 4.19 & Yes \\
\hline
\end{tabular}

Source: Author's construction

\section{DISCUSSION}

Hypothesis 1 suggested a significant influence of performance expectancy on behavioral intention. However, this study could not support this hypothesis. This study found an insignificant association between performance expectancy and behavioral intention to adopt e-commerce among gen $\mathrm{Z}$ in Ghana. This finding contradicts the findings of other studies that have found a significant relationship between performance expectancy and behavioral intention (Datta 2011, Lin \& Anol 2008, Moghawemi et al. 2012, Raman \& Don 2013, Raman et al. 2014, Ramayah et al. 2005), but supports the findings of Faraliza et al. (2014), Lian (2015), Singeh et al. (2013), and Yueh et al. (2015). This finding suggests that the perceived gains of using e-commerce platforms for purchases do not regress significantly on gen Z's behavioral intention to adopt e-commerce. It concludes that gen $\mathrm{Z}$ in Ghana is not interested in the utilitarian aspect of e-commerce. 
This study also found a positive and significant relationship between effort expectancy and behavioral intention to adopt e-commerce among gen $\mathrm{Z}$ in Ghana. This finding supports hypothesis 2. This finding is consistent with Madigan et al. (2016), Hogue \& Sowar (2017), Escobar-Rodríguez \& Carvajal-Trujillo (2014), Fang (2014), Hsu et al. (2017), Im et al. (2011), Venkatesh et al. (2011). According to this study, effort expectancy was the second major factor that predicts behavioral intention to use e-commerce by gen $\mathrm{Z}$ in Ghana. Studies show that when the ease of using a system increases, behavioral intention to use the system also increases, which has been proven by Gen $\mathrm{Z}$ in Ghana.

Hypothesis 3 suggested a significant association between social influence and behavioral intention. However, the findings of this study could not provide support for this hypothesis. This study found social influence to have an insignificant influence on behavioral intention to adopt e-commerce among gen $\mathrm{Z}$ in Ghana. This finding is in line with studies such as Addo (2014), Faaeq et al. (2014), Faraliza et al. (2014), Nassuora (2013), Nysveen \& Pedersen (2014). This result means the perception of others does not influence the gen Z's adoption behavior in Ghana. This study also found a significant relationship between facilitating conditions and e-commerce adoption among gen $\mathrm{Z}$. This confirms hypothesis 4 . This supports the findings of Lin \& Anol (2008), Moghawemi et al. (2012), Sanchez et al. (2014), Wu et al. (2007), Chang (2013), Guo (2015).

Information quality predicted the largest variance in the intention to adopt e-commerce among gen $\mathrm{Z}$ in Ghana. This finding supports hypothesis 5. This finding supports Abdennebi \& Debabi (2017) and Liébana- Cabanillas et al. (2017), who found that information quality positively influenced e-commerce adoption. This suggests that information quality is a significant factor in e-commerce adoption among gen $\mathrm{Z}$ in Ghana. This study also found a significant association between system quality and behavioral intention. This finding is consistent with DeLone and Mclean (2004), Shergill \& Chen (2005), Elliott \& Speck (2015). Furthermore, service quality showed an insignificant relationship with behavioral intention to adopt e-commerce among gen $Z$. therefore, this study could not support hypothesis 7. This finding is similar to Hogue \& Sowar (2017), Madigan et al. (2016), Tarhini et al. (2018), Rahi et al. (2018), Raza et al. (2019), Savic $\&$ Pesterac (2019). However, this finding contradicts Moorthy et al. (2017) and Hsu \& Yeh (2018). Finally, this study reported a significant relationship between behavioral intention and actual adoption of e-commerce by Ghanaian gen Z this confirms hypothesis 8 . This supports studies such as Hogue \& Sowar (2017), Madigan et al. (2016), Tarhini et al. (2018), Rahi et al. (2018), Raza et al. (2019), Savic \& Pesterac (2019)

\section{CONCLUSION}

\section{Theoretical implications}

This research makes significant contributions to the literature on e-commerce. It extends the literature on e-commerce adoption in developing countries (in this case, Ghana) by modeling the factors that influence gen $\mathrm{Z}$ to adopt e-commerce. Most of the literature that investigated e-commerce adoption focused on macro and meso perspectives of e-commerce adoption. Research into a micro perspective, especially among gen $\mathrm{Z}$ and e-commerce adoption, has been overlooked and unattended by researchers. This study is, arguably, the first of its kind to study the e-commerce adoption behavior among gen $\mathrm{Z}$ in Ghana. This current study enriches and provides a better understanding of the determinants of e-commerce adoption among gen $\mathrm{Z}$ in Ghana.

\section{Practical implications}

The paper concludes that the ease of using online shopping applications, the readiness and availability of support service for online purchases, information quality, and the efficiency and reliability of e-commerce systems significantly influence gen $\mathrm{Z}$ adoption of e-commerce. As a result, e-vendors and website business designers should ensure that the design and layout of e-commerce websites must be easy for consumers to navigate, provide a 24-hour consumer support system, and ensure efficiency and reliability of the e-commerce system.

\section{Limitations and future research direc- tions}

Besides the contribution this research brings to e-commerce literature, it is not without limitations. First, the study modeled the factors that influence the adoption of e-commerce among gen $\mathrm{Z}$ in Ghana. There is a need for support of findings with data from other developing countries. Another limitation lies in the methodology. Data were collected using a cross-sectional survey which does not permit the interpretation of causal inferences between const- 
ructs. Some studies, such as Zmud (1982), indicate that diffusion of innovation is a social process whereby behavioral intention to adopt a technology develops over time. Therefore, the cross-sectional survey data may not give a better picture of the adoption behavior. Longitudinal research to systematically investigate the adoption behavior over some time may reveal exciting insights and provide a better understanding of e-commerce adoption among gen Z. Finally, future studies can incorporate constructs such as perceived online security and perceived online trust into the research model to investigate their effect on gen $\mathrm{Z}$ adoption of e-commerce.

\section{REFERENCES}

Addo, H. (2014). Using the UTAUT model to analyze students' ICT adoption. International Journal of Education and Development using Information and Communication Technology, 10(3), 75-86

Agwu, M. O. and Emeti, C. I. (2014). Issues, challenges and prospects of small and medium scale enterprises (SMEs) in Port-Harcourt City, Nigeria. European Journal of Sustainable Development, 3(1), 101-14

Alrajawy, I., Daud, N. M., Isaac, O., and Mutahar, A. M. (2016). Factors influence intention to use mobile learning within public universities students in Yemen In The 7th international conference postgraduate education (ICPE7) (10501064). Malaysia: Shah Alam.

Awiagah, R., Kang, J. and Lim, J. (2015). Factors affecting e-commerce adoption among SMEs in Ghana. Information Development, 32(4), 815-36

Bagozzi, R. P. and Yi, Y. (2012). Specification, evaluation, and interpretation of structural equation models. Journal of the Academy of Marketing Science, 40(1), 8-34

Boateng, R. (2016). Resources, Electronic-Commerce Capabilities and Electronic-Commerce Benefits: Conceptualizing the Links. Information Technology for Development, 22(2), 242-64

Chang, C. C. (2013). Library mobile applications in university libraries. Library Hi Tech, 31(3), 478-92

Chiliya, N., Chikandiwa, C. and Afolabi, B. (2011. Factors Affecting Small Micro Medium Enterprises' (SMMEs) Adoption of E-Commerce in the Eastern Cape Province of South Africa International Journal of Business \& Manage- ment, 6(10), 18-29

Chin, W. W., Marcolin, B. and Newsted, P. (2003). A partial least squares latent variable modeling approach for measuring interaction effects: Results from a Monte Carlo simulation study and an electronic-mail emotion/adoption study. Information Systems Research, 14(2), 189-217

Choi, S. (2017). What promotes smartphone-based mobile commerce? Mobile-specific and self-service characteristics. Internet Research, 28(2), 1014-38

Datta, P. (2011). A preliminary study of ecommerce adoption in developing countries. Information Systems Journal, 21(1), 3-32

DeLone, W. H. and Mclean, E. R. (2004). Measuring e-commerce success: applying the DeLone and McLean information systems success model. International Journal of Electronic Commerce, 9(1), 31-47

Elliott, M. T. and Speck, P. S. (2005). Factors that affect attitude toward a retail web site. Journal of Marketing Theory and Practice, 13(1), 40-51

Eraslan, E., Tansel, Y. and Yurdakul. M. (2016). A new usability evaluation approach for touch screen mobile devices. Int. J. of Business and Systems Research, 10(2-4), 186-219

Escobar-Rodríguez, T., and Carvajal-Trujillo, E. (2014). Online purchasing tickets for low-cost carriers: An application of the unified theory of acceptance and use of technology (UTAUT) model. Tourism Management, 43(1), 70-88

Faaeq, M. K., Alqasa, K., and Al-Matari, E. M. (2014). Technology adoption and innovation of E-Government in Republic of Iraq. Asian Social Science, 11(3), 135-45

Fang, S. F. (2014). Using UTAUT model to explore the user behavior of E-learning system in a public sector. Department of Communications Management.

Faraliza, N., Noor, M., Azmi, A. A. C. and Ramalingam, L. (2014). The unified theory of acceptance and use of technology (UTAUT) and the goods and service tax (GST) application system. Research Journal of Applied Sciences, Engineering and Technology, 8(17), 1911-16

Fishbein, M. and Ajzen, I. (1975). Belief, attitude, intention and behavior: An introduction to theory and research. Boston, MA: Addison-Wesley

Fichman, R. (2004). Going beyond the dominant paradigm for information technology innovation research: emerging concepts and methods. Journal of Association of Information Systems, 5(8), 314-55 https://doi.org/10.17705/ 1jais.00054. 
Gonzalez, G. C., Sharma, P. N., and Galletta, D. (2012). Factors influencing the planned adoption of continuous monitoring technology. Journal of Information Systems, 26(2), 53-69

Gorla, N., Chiravuri, N. and Chinta, R. (2017). Business to Business e-commerce adoption: An empirical investigation of business factors. Information systems frontiers, 19, 645-67

Guo, Y. (2015). Moderating effects of gender in the acceptance of mobile SNS based on UTAUT model. International Journal of Smart Home, 9(1), 203-16

Hair, J. F., Jr., Black, W. C., Babin, B. J., Anderson, R. E. and Tatham, R. L. (2006). Multivariate Data Analysis, 6th ed., Prentice Hall, Upper Saddle River, NJ

Heang, J. F. and Khan, H. U. (2015). The role of internet marketing in the development of agricultural industry: a case study of China. Journal of Internet Commerce, 14(1), 1-49

Heinze, J., Thomann, M. and Fischer, P. (2017). Ladders to $\mathrm{m}$-commerce resistance: a qualitative means-end approach. Computers in Human Behavior, 73, 362-74

Hendarman, A. F., and Tjakraatmadja, J. H. (2012). Relationship among soft skills, hard skills, and innovativeness of knowledge workers in the knowledge economy era. Procedia - Social and Behavioral Sciences, 52(1), 35-44

Hogue, R. and Sowar, G. (2017). Understanding factors influencing the adoption of mHealth by the elderly: an extension of the UTAUT model. International Journal of Medical Informatics, 101, 75-84

Hsu, C. L., Chen, M. C., Lin, Y.-H., Chang, K. C., and Hsieh, A. Y. (2017). Adopting the Extension of UTAUT Model to Investigate the Determinants of e-book Adoption. Program: electronic library and information systems, 51(1), 2-16

Hsu, C. W. and Yeh, C. C. (2018). Understanding the critical factors for successful M-commerce adoption. International Journal of Mobile Communications, 16(1), 50-62

Ifinedo, P. (2012). Technology acceptance by health professionals in Canada: An analysis with a modified UTAUT model. Proceedings of the Annual Hawaii International Conference on System Sciences, 2937-46

Im, I., Hong, S., and Kang, M. S. (2011). An international comparison of technology adoption: Adoption testing the UTAUT model, Information \& Management, 48(1), 1-8

Isaac, O., Abdullah, Z., Ramayah, T., and Mutahar, A. M. (2017). Examining the relationship between overall quality, user satisfaction and internet usage: An integrated individual, technological, organizational and social perspective. Asian Journal of Information Technology, 16(1), 100-24

Khalilzadeh, J., Ozturk, A. and Bilgihan, A. (2017). Security-related factors in extended UTAUT model for NFC based mobile payment in the restaurant industry. Computers in Human Behaviour, 70, 460-474

Khan, H. U., Omonaiye, J. F. and Madhavi Lalitha, V. V. (2017). Employees' perception as internal customers about online services: a case study of banking sector in Nigeria. International Journal of Business Innovation and Research, 13(2), 181-202

Li, L. and Wang, X. (2018). M-Commerce adoption in SMEs of China: the effect of institutional pressures and the mediating role of top management. Journal of Electronic Commerce in Organizations (Organizations), 16(2), 48-63

Lian, J. W. (2015). Critical factors for cloud-based e-invoice service adoption in Taiwan: An empirical study. International Journal of Information Management, 35(1), 98-109

Liébana-Cabanillas, F., Marinkovic, V. and Kalinic, Z. (2017). A SEM-neural network approach for predicting antecedents of m-commerce acceptance. International Journal of Information Management, 37(2), 14-24

Lin, C. P., and Anol, B. (2008). Learning online social support: An investigation of network information technology based on UTAUT. Cyber Psychology and Behavior: The Impact of the Internet, Multimedia and Virtual Reality. Behavior and Society, 11(3), 268-72

Liu, C. and Forsythe, S. (2011). Examining drivers of online purchase intensity: moderating role of adoption duration in sustaining post-adoption online shopping. Journal of Retailing and Consumer Services, 18(1), 101-9

Lyytinen, K. and Rose, G. (2003). The Disruptive Nature of Information Technology Innovations: The Case of Internet Computing in Systems Development Organizations. MIS Quarterly, 27(4), 557-95 DOI: 10.2307/30036549

Madan, K. and Yadav, R. (2018). Understanding and predicting antecedents of mobile shopping adoption: a developing country perspective. Asia Pacific Journal of Marketing and Logistics, 30(1), 139-62

Madigan, R., Louw, T., Dziemus, M. and Graindorge, T. (2016). Acceptance of road transport systems (ARTS): an adoption of UTAUT model. Transportation research, 14, 2217-26 
Martins, C., Oliveira, T. and Popovic, A. (2014) Understanding the internet banking adoption: A unified theory of acceptance and use of technology and perceived risk application.. International Journal of Information Management, 34(1), 1-13

Moghawemi, S., Mohd Salleh, N. A., Zhao, W. and Mattila, M. (2012). The entrepreneur's perception on information technology innovation adoption: An empirical analysis of the role of precipitating events on usage behavior. Innovation, Management, Policy \& Practice, 14(2), 231-46

Moorthy, K., Suet Ling, C., Weng Fatt, Y. and Kok Wei, L. (2017). Barriers of mobile commerce adoption intention: perceptions of generation $\mathrm{X}$ in Malaysia. Journal of Theoretical and Applied Electronic Commerce Research, 12(2), 37-53

Nassuora, A. (2013). Students acceptance of mobile learning for higher education in Saudi Arabia. International Journal of Learning Management Systems, 1(1), 1-9

Nysveen, H. and Pedersen, P. E. (2014). Consumer adoption of RFID-enabled services. Applying an extended UTAUT model. Information Systems Frontiers. DOI: 10.1007/s10796-0149531-4

Pobee, F. and Opoku, D. (2018). The Moderating Effects of Gender on E-Commerce Systems Adoption Factors. International Journal of Strategic Decision Sciences, 9(4), 86-104

Rahayu, R. and Day. J. (2015). E-commerce adoption by SMEs in developing countries: evidence from Indonesia. Eurasian Bus Rev, 7, 25-41

Rahi, S., Ghani, M. and Alnaser, F. (2018). Investigating the role of UTAUT in internet banking context. Management Science, 8(3), 173-86

Raman, A. and Don, Y. (2013). Preservice teachers acceptance of learning management software An application of the UTAUT2 model. International Education Studies, 6(7), 157-64

Raman, A., Don, Y., Khalid, R., Hussin, F., Omar, M. S., and Ghani, M. (2014). Technology acceptance on smart board among teachers in Terengganu using UTAUT model. Asian Social Science, 10(11), DOI: 10.5539/ass.v10n11p84.

Ramayah, T., Ignatius, J. and Aafaqi, B. (2005). PC usage among students in A private institution of higher Learning: The moderating role of prior experience. Jurnal Pendidik Dan Pendidikan, 20(1), 131-52

Raza, S., Shah, N. and Ali, M. (2019). Acceptance of mobile banking in Islamic banks: Evidence from modified UTAUT model. Journal of Islamic Marketing, 0(1), 357-76
Sanchez, R., Cortijo, V. and Javed, U. (2014). Students' perceptions of Facebook for academic purposes. Computers \& Education, 70(1), 13849

Savic, J. and Pesterac, A. (2019). Antecedents of mobile banking: UTAUT model. The European journal of applied economics, 16(1), 20-9

Shergill, G. S. and Chen, Z. (2005). Web-Based shopping: consumers' attitudes towards online shopping in New Zealand. Journal of Electronic Commerce Research, 6(2), 78-94

Singeh, F. W., Abrizah, A. and Karim, N. H. A. (2013), "Malaysian authors' acceptance to self-archive in institutional repositories: Towards a unified view", The Electronic Library, 31 2, 188-207

Taiwo, A., Mahmood, A., and Downe, A. (2012). User acceptance of eGOVERNMENT: Integrating risk and trust dimensions with UTAUT model. 2012 International Conference onCcomputer \& Information Science (ICCIS) (pp. 4-8).

Tarhini, A., Alalwan, A., Al-Qirim, N., Algharabat, R. and Masa'deh, R. (2018). An analysis of the factors influencing the adoption of online shopping. International Journal of Technology Diffusion, 9(3), 68-87

Toh, C. H. (2013). Assessing adoption of wikis in a Singapore secondary school: Using the UTAUT model. Proceedings of the 2013 IEEE 63rd annual conference international council for education Media (1-9). ICEM, 2013

UNCTAD (2020), Global E-Commerce hits \$25.6 trillion - latest UNCTAD estimates. Available at: https://unctad.org/en/pages/PressRelease. aspx? OriginalVersionID $=552$. (assessed July 7, 2020)

Vasileiadis, A. (2014). Security concerns and trust in the adoption of m-commerce. Socialines Technologijos, 4(1), 179-191 DOI: 10.13165/ st-14-4-1-12

Venkatesh, V., Morris, M., Davis, F. and Davis, G. (2003). User acceptance of information technology: towards a unified view. MIS Quarterly, 27(3), 425-78 DOI: 10.2307/30036540

Venkatesh, V., Thong, J. Y. L., Chan, F. K. Y., Hu, P. J. H. and Brown, S. (2011). Extending the two-stage information systems continuance model: Incorporating UTAUT predictors and the role of context. Information Systems Journal, 21(6), 527-55 DOI: 10.1111/j.13652575.2011.00373.x

Wood, S. (2013). Generation Z as Consumers: Trends and Innovation. NC State University. Institute for emerging issues. 
Wu, Y., Tao, Y. and Yang, P. (2007). Using UTAUT to explore the behavior of $3 \mathrm{G}$ mobile communication users. 2007 IEEE international conference on industrial engineering and engineering management (199-203)

Yang, S. (2013). Understanding undergraduate students' adoption of mobile learning model: A perspective of the extended UTAUT2. Journal of Convergence Information Technology, 8(10), 969-79 DOI: 10.4156/jcit.vol8.issue10.118

Yueh, H., Huang, J. and Chang, C. (2015). Exploring factors affecting students' continued Wiki use for individual and collaborative learning: An extended UTAUT perspective. Australasian Journal of Educational Technology, 31(1), 16-31 DOI: 10.14742/ajet.170
Zhou, T., Lu, Y., and Wang, B. (2010). Integrating TTF and UTAUT to explain mobile banking user adoption. Computers in Human Behavior, 26(4), 760-7

Zmud, R. (1982). Diffusion of modern software practices: influences of centralization and formalization. Management Science, 28(1), 142131

Frederick Pobee, $\mathrm{PhD}$ Student pobee.fred@gmail.com

University of Pecs

Faculty of Business and Economics 